\title{
РОЛЬ ОКСИДАТИВНОГО СТРЕСУ В РОЗВИТКУ ХРОНІЧНОГО ОБСТРУКТИВНОГО ЗАХВОРЮВАННЯ ЛЕГЕНЬ
}

Вступ. Поширеність хронічного обструктивного захворювання легень (ХОзЛ) продовжує неухильно зростати. На думку дослідників, до 2030 р. воно стане третьою за значимістю причиною смертності. Патофрізіологія ХОЗЛ складна і на даний час до кінця не вивчена. Більшість дослідників у хворих на ХОЗЛ визначає локальні та системні зміни, що включають оксидативний стрес, зміну рівнів гострофразових протеїнів і запальних медіаторів, хоча й немає єдиної точки зору щодо їх ролі при цьому захворюванні.

У роботі використано загальнонаукові методи дослідження, що включають експертно-аналітичний огляд наукових джерел, аналіз і синтез літературних даних.

Дослідники зазначають, що пероксидне окиснення протеїнів $є$ не тільки пусковим механізмом патологічних процесів при стресі, але й одним з найбільш ранніх маркерів оксидативного стресу, а також відображенням ступеня окиснювального ураження клітин та резервно-адаптаційних можливостей організму при ХОЗЛ. Оксидативний стрес призводить до окиснення арахідонової кислоти і фрормування нової генерації простаноїдних медіаторів, так званих ізопростанів, які можуть проявляти виражені фуннкціональні ефекти, включаючи бронхоконстрикцію та ексудацію плазми. Негативним ефектам оксидативного стресу в організмі протидіють ензимна і неензимна ланки системи антиоксидантного захисту. Високу антиоксидантну ефективність проявляють мідь-цинковмісна супероксиддисмутаза, гемовмісна каталаза, селеновмісна глутатіонпероксидаза. За результатами аналізу літературних джерел, внутрішньоклітинний антиоксидант глутатіон є головною захисною системою в епітелії легень. Захисні ефекти спорідненої антиоксидантної системи, розташованої в епітелії, імовірно, регулюють гени. Це може бути однією з причин, чому лише в 10 \% осіб, які курять, розвивається ХОЗЛ.

Мета дослідження - проаналізувати сучасні літературні джерела про роль вільнорадикальних процесів у механізмах розвитку хронічного обструктивного захворювання легень.

Висновок. Проведений аналіз літературних даних показав, що оксидативний стрес відіграє вагому роль у патогенезі хронічного обструктивного захворювання легень, проте механізми його впливу потребують детальнішого і глибшого дослідження.

КЛЮЧОВІ СЛОВА: хронічне обструктивне захворювання легень; оксидативний стрес; механізми.

Поширеність хронічного обструктивного захворювання легень (ХОЗЛ) продовжує неухильно зростати. На думку дослідників, до 2030 р. воно стане третьою за значимістю причиною смертності [1]. В усьому світі 10-20 \% населення віком понад 40 років (близько 80 млн) страждають від ХОЗЛ [2]. Щогодини від цього захворювання помирає близько 250 пацієнтів, і це більше, ніж від раку молочної залози та інших патологій легень [3]. Результати досліджень свідчать про те, що ХОЗЛ є тихим убивцею в країнах з низьким та середнім рівнями доходу через поширене тютюнокуріння і забруднення повітря [4].

Обструкція повітряних шляхів при ХОЗЛ характеризується поступовою втратою фрункцій (с) Х. Я. Максів, М. І. Марущак, 2019. легень внаслідок поєднання захворювань дихальних шляхів (наприклад, обструктивного бронхіоліту) і паренхіматозної деструкції (наприклад, емсріземи) [5]. Патофрізіологія цього захворювання складна і на даний час до кінця не вивчена. Більшість дослідників у хворих на ХОЗЛ визначає локальні та системні зміни, що включають оксидативний стрес, зміну рівнів гострофразових протеїнів і запальних медіаторів, у тому числі інтерлейкінів (ІЛ) 8 та 4, фрактора некрозу пухлини $\alpha$ (ФНП- $\alpha)$, хоча й немає єдиної точки зору щодо їх ролі при цьому захворюванні [6]. Вважають, що оксидативний стрес розвивається у хворих на ХОЗЛ внаслідок хронічного впливу сигаретного диму через високу концентрацію окиснювачів і реактивних фрорм оксигену [7]. Тютюновий дим залишається ключовою причи- 
ною ХОЗЛ у всьому світі. Враховуючи те, що сигаретний дим містить тисячі шкідливих речовин, його патогенність не може бути вивчена при дослідженні лише однієї сполуки. Крім нікотину, важких металів і канцерогенів, тютюновий дим призводить до значного впливу таких оксидантів, як алкільні, алколільні та пероксильні органічні вільні радикали, $\alpha-$, $\beta$-ненасичені альдегіди, супероксид, $\mathrm{N}_{2} \mathrm{O}$ й оксид азоту, що потребує глибшого дослідження [8].

За фрізіологічних умов у живому організмі постійно перебігають процеси, які супроводжуються продукуванням активних фрорм оксигену (АФО), а також процеси, пов'язані з їх участю [9]. Кисневі радикали генеруються при гіпоксії, ішемії-реперсузії, гіпероксії, диссрункції мітохондрій, ушкодженні ендотелію, метаболізмі ненасичених жирних кислот [10]. Активні фоорми оксигену можуть призводити до деструкції мембран і ушкодження клітин незалежно від активності системи антиоксидантного захисту [11]. Порушення роботи будь-якої ділянки дихального ланцюга зумовлює продукування АФО, при цьому характер впливу цих фрорм залежить від вмісту їх у клітині. Так, незначне зростання генерації АФО призводить до гіпоксичної адаптації за допомогою HIF1 $\alpha$-опосередкованої регуляції, помірне - до формування запальної відповіді, значне - до фрормування пор у мембранах мітохондрій, активації гена ATG-4 3 подальшою аутофагією та апоптозом [12]. Науковці зазначають, що АФО, у свою чергу, індукують продукування прозапальних цитокінів у клітинах імунної системи за рахунок активації RIG-I-подібних рецепторів, мітогенактивованих протеїнкіназ й інфламасом [13]. Було встановлено ме-

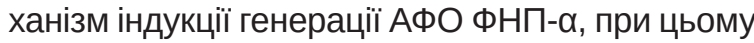
останній чинить стимулювальну дію на $\mathrm{Ca}^{2+}$-залежний шлях утворення АФО, тоді як концентрація ФНП- $а$ зростає при запальних захворюваннях дихальних шляхів $[14,15]$. Під час дослідження медіаторів запалення з'ясовано, що рівень лейкоцитів, концентрація ФНП- $\alpha$ та ІЛ-8, як і рівень фрібриногену й ІЛ-6, були найбільшими у хворих на ХОЗЛ стосовно пацієнтів, які не мали даного захворювання [16]. Необхідно відзначити, що рівень лейкоцитів, концентрація ФНП- $\alpha$ та ІЛ-8 також були підвищені в пацієнтів, які не мали ХОЗЛ, проте курили, порівняно з контролем (особи без ХОЗЛ і які не курили) [17]. Таким чином, ХОЗЛ є системним запальним захворюванням 3 акцентом на запаленні легень.

Оксидативний стрес $€$ ключовою частиною ланцюга подій, що призводять до запалення. Гранулоцитарні пероксидази виконують фрункцію тригерів в оксидативному стресі [18]. Вважають, що АФО й оксидативний стрес відіграють цен- тральну роль у виникненні дисфункції клітин та ушкодження тканин. Активні форми оксигену також модулюють ряд сигнальних шляхів клітин, що спричиняє активацію фрактора транскрипції та вивільнення медіаторів запалення [19]. Вони індукують трансдукцію сигналу молекули адгезії судинних клітин-1 (VCAM-1) [20]. Залучення вільних кисневих радикалів у патологічний процес пов'язане з багатьма захворюваннями дихальної системи, зокрема ХОЗЛ, гострим респіраторним дистрес-синдромом, бронхолегеневою дисплазією, емфіземою, пневмоконіозом, гіпероксією, муковісцидозом і бронхіальною астмою [21].

За умови ХОЗЛ активовані в дихальних шляхах нейтрофіли, макрофраги й епітеліальні клітини продукують АФО. Супероксидні аніони, які генерує NADPH-оксидаза, перетворюються в гідроген пероксид $\left(\mathrm{H}_{2} \mathrm{O}_{2}\right)$ за допомогою супероксиддисмутази. $\mathrm{H}_{2} \mathrm{O}_{2}$ потім перетворюється у воду завдяки каталазі. Супероксидні аніони можуть взаємодіяти $3 \mathrm{H}_{2} \mathrm{O}_{2}$ за присутності вільного фреруму 3 утворенням високореактивного гідроксильного радикала (.OH) або ж поєднуватися 3 NO 3 утворенням пероксинітриту, який також генерує · ОН. Активні фрорми оксигену зумовлюють ланцюгові реакції в ліпідах з накопиченням ліпідних радикалів LJ, LOOJ, LOOH i алкоксилів LOJ. Це призводить до вільнорадикального окиснення, яке включає ініціацію і продовження ланцюга, а реакція $\mathrm{LOOH} 3 \mathrm{Fe}^{2+}$ зумовлює його розгалуження, що в результаті завершується утворенням мінорних метаболітів: малонового діальдегіду, етану, пентану [22]. Малоновий діальдегід є основним продуктом пероксидного окиснення ліпідів, який відповідає за цитопатологічні ефекти [23]. Гідропероксиди та АФО атакують інші структури клітин, такі, як протеїни і дезоксирибонуклеїнова кислота [24]. Дослідники зазначають, що пероксидне окиснення протеїнів $€$ не тільки пусковим механізмом патологічних процесів при стресі, але й одним 3 найбільш ранніх маркерів оксидативного стресу, а також відображенням ступеня окиснювального ураження клітин та резервно-адаптаційних можливостей організму при ХОЗЛ [16, 25]. Оксидативний стрес призводить до окиснення арахідонової кислоти і формування нової генерації простаноїдних медіаторів, так званих ізопростанів, які можуть проявляти виражені фрункціональні ефректи, включаючи бронхоконстрикцію та ексудацію плазми [26]. Крім того, зростання 8-ізопростану при ХОЗЛ є додатковим маркером запалення в дихальних шляхах, який корелює безпосередньо з обструкцією дихальних шляхів [27].

Гіперсекреція слизу, що виникає під дією ксантиноксидаз, може викликати обмеження 
проходження повітря по дихальних шляхах [28]. Посилення продукування слизу внаслідок епітеліального росту, стимульованого окиснювальними агентами, відбувається разом із порушенням циліарної системи, що сприяє більшому накопиченню i, нарешті, застою слизу в дихальних шляхах [29].

Негативним ефректам оксидативного стресу в організмі протидіють ензимна і неензимна ланки системи антиоксидантного захисту. Ïх активність залежить від стереоелектронних есректів ароматичного і хроматинового кілець, орто- та параположення гідроксильних груп антиоксидантів, тіолових сполук, хелатування металів змінної валентності, рецепторних взаємодій із клітинною мембраною та від інших властивостей. Високу антиоксидантну есеективність проявляють мідь-цинковмісна супероксиддисмутаза, гемовмісна каталаза, селеновмісна глутатіонпероксидаза. За результатами аналізу літературних джерел, внутрішньоклітинний антиоксидант глутатіон $€$ головною захисною системою в епітелії легень [30]. Захисні есректи спорідненої антиоксидантної системи, розташо-

\section{СПИСОК ЛІТЕРАТУРИ}

1. Роль цитокінового дисбалансу в розвитку та прогресуванні хронічного обструктивного захворювання легень із супутнім хронічним панкреатитом / Т. М. Христич, О. І. Федів, Я. М. Телекі, О. Ю. Оліник // Новости медицины и фармации. Гастроэнтерология. - 2011. - № 382. - С. 64-66.

2. Bhandari R. Epidemiology of chronic obstructive pulmonary disease: a descriptive study in the midwestern region of Nepal / R. Bhandari, R. Sharma // International Journal of COPD. - 2012. - 7. - P. 253-257.

3. Перцева Т. А. Эпидемиология и диагностика хронического обструктивного заболевания легких / Т. А. Перцева // Укр. пульм. журн. - 2011. - № 2. - С. 20.

4. Alwan A. Global status report on non-communicable diseases / A. Alwan // Global Status Report on Noncommunicable Diseases. - 2010. - P. 176.

5. Prevalence of chronic obstructive pulmonary disease in the global population with HIV: a systematic review and meta-analysis / J. J. Bigna, A. M. Kenne, S. L. Asangbeh, A. T. Sibetcheu // Lancet Glob. Health. 2018. - 6. - P. 193-202.

6. Stone $\mathrm{H}$. Variability of sputum inflammatory mediators in COPD and $\alpha 1$-antitrypsin deficiency / $\mathrm{H}$. Stone, G. M. Nab, A. M. Wood // Eur. Respir. J. - 2012. - 40. P. 561-569.

7. The determination of correlation linkages between level of reactive oxygen species, contents of neutrophiles and blood gas composition in experimental acute lung injury / M. Marushchak, I. Krynytska, N. Petrenko, I. Klishch // Georgian Med News. - 2016. - 253. P. 98-103. ваної в епітелії, імовірно, регулюють гени. Це може бути однією з причин, чому лише в $10 \%$ осіб, які курять, розвивається ХОЗЛ [31]. Головний антиоксидантний транскрипційний фрактор Nrf2 недавно було включено до широкого діапазону патогенетичних змін легень. Він контролює понад 100 генів, що беруть участь в антиоксидантному захисті [32]. У мишей, в яких відсутній орактор Nrf2, спостерігають підвищену сприйнятливість до запалення легень при гострому впливі сигаретного диму, підвищену експресію RTP801, а при хронічному впливі - також підвищену сприйнятливість до апоптозу альвеолярних клітин і розвитку емфріземи [33].

Проведений аналіз літературних даних показав, що оксидативний стрес відіграє вагому роль у патогенезі хронічного обструктивного захворювання легень, проте механізми його впливу потребують детальнішого і глибшого дослідження.

Перспективи подальших досліджень полягають у поглибленому вивченні особливостей вільнорадикального окиснення при коморбідності у хворих на ХОЗЛ.
8. Rubin M. Tuder Pathogenesis of chronic obstructive pulmonary disease / M. R. Tuder, I. Petrache // J. Clin. Invest. - 2012. - 122 (8). - P. 2749-2755.

9. Kohen R. Oxidation of biological systems: oxidative stress phenomena, antioxidants, redox reactions, and methods for their quantification / R. Kohen, A. Nyska // Toxicol. Pathol. - 2002. - 30 (6). - P. 620-650.

10. Роль оксидативного стресса в патогенезе заболеваний новорожденных детей / Г. А. Шишко, А. В. Сапотницкий, Ю. А. Устинович [и др.] //Белорусс. мед. акад. последипломного образования. - 2011. № 6. - C. 22-24.

11. Mishra O. P. Cellular mechanisms of hypoxic injury in the developing brain / O. P. Mishra, M. D. Papadopoulos // Brain Res. Bull. - 1999. - 48. - P. 233238.

12. Li X. Targeting mitochondrial reactive oxygen species as novel therapy for inflammatory diseases and cancers / X. Li, P. Fang, J. Mai // J. Hematol. Oncol. 2013. - 6. - P.1-19.

13. West A. P. Mitochondria in innate immune responses / A. P. West, G. S. Shadel, S. Ghosh // Nat. Rev. Immunol. - 2011. - 11 (6). - P. 389-402.

14. Dada L. A. Mitochondrial $\mathrm{Ca}^{2+}$ and ROS take center stage to orchestrate TNF- $\alpha-$ mediated inflammatory responses / L. A. Dada, J. I. Sznajder // J. Clin. Invest. 2011. - 121 (5). - P. 1683-1685.

15. Балаболкин М. И. Роль окислительного стресса в патогенезе диабетической нейропатии и возможность его коррекции препаратами $\alpha$-липоевой кислоты / М. И. Балаболкин, В. М. Креминская, Е. М. Кле- 
банова // Проблемы эндокринологии. - 2005. № 51 (3). - С. 22-33.

16. Клименко М. О. Несрерментативна ланка антиоксидантної системи в різні стадії експериментальної опікової хвороби при використанні препарату "Кріохор" / М. О. Клименко, Н. П. Субота, Л. Г. Нетюхайло // Експерим. і клініч. медицина. - 2006. - № 1. C. 13-17.

17. Imaizumi Y. Lung Disease and Hypertension / Y. Imaizumi, K. Eguchi, K. Kario // Pulse. - 2015. 2 (1-4). - P. 103-112.

18. Analysis of oxidative stress in exhaled breath condensate from patients with severe pulmonary infections / P. V. Romero, B. Rodríguez, S. Martínez [et al.] // Archivos de Bronconeumologia. - 2006. - 42 (3). P. 113-119.

19. Zhang W. Genetic deficiency of NADPH oxidase does not diminish, but rather enhances, LPS-induced acute inflammatory responses in vivo / W. Zhang, H. Wei, B. Frei // Free Radical Biology and Medicine. - 2009. 46 (6). - P. 791-798.

20. Mills M. C. Vascular cell adhesion molecule-1 expression and signaling during disease: regulation by reactive oxygen species and antioxidants / M. C. Mills, M. E. Marchese, H. A. Valencia // Antioxidants \& Redox Signaling. - 2011. - 15 (6). - P. 1607-1638.

21. Level of antioxidant vitamins in children suffering from pneumonia / G. M. Bhoite, S. M. Pawar, M. P. Bankar, A. A. Momin // 2011. - Mode access : https://www. alliedacademies.org/articles/level-of-antioxidant-vitamins-in-children-suffering-from-pneumonia.pdf

22. Нетюхайло Л. Г. Активні фрорми кисню (огляд літератури) / Л. Г. Нетюхайло, С.В.Харченко // Young Scientist. - 2014. - № 9 (12). - C. 131-135.

23. Vaidya N. A. Antioxidant enzymes and antioxidants in children with Pneumonia / N. A. Vaidya, P. M. Bu- lakh // IOSR Journal of Dental and Medical Sciences. 2013. - 8 (6). - P. 01-05.

24. Young E. J. Principles and practice of infectious diseases / E. J. Young // Philadelphia: Churchill Livingstone. - 2005. - P. 2669-2672.

25. Клименко М. О. Опікова хвороба (патогенез і лікування) : монографрія / М. О. Клименко, Л. Г. Нетюхайло. - Полтава, 2009. - 118 с.

26. Montuschi P. Isoprostanes: markers and mediators of oxidative stress / P. Montuschi, P. J. Barnes, L. J. Roberts // FASEB J. - 2004. - 18. - P. 1791-800.

27. Rezaeetalab F. Prooxidant - antioxidant balance in COPD patients / F. Rezaeetalab, D. H. Alamdari, A. Dalili // Pneumologia. - 2017. - 66 (2). - P. 90-93.

28. Rogers D. F. Mucus hypersecretion in chronic obstructive pulmonary disease / D. F. Rogers, D. Chadwick, J. A. Goode // Chronic obstructive pulmonary disease: pathogenesis to treatment. - UK, 2001. - P. 65-83.

29. Nadel J. A. Role of epidermal growth factor receptor activation in regulating mucin synthesis / J. A. Nadel // Respir. Res. - 2001. - 2. - P. 85-89.

30. Rezaeetalab F. Oxidative stress in COPD, pathogenesis and therapeutic views / F. Rezaeetalab, D. H. Alamdari, A. Dalili // Treat Respir. Med. - 2014. 1 (3). - P.115-124.

31. Higgins M. Incidence, prevalence, and mortality: intra- and inter-county differences / M. Higgins, T. Thom // Clinical Epidemiology of Chronic Obstructive Pulmonary Disease. - 1990. - P. 23-43.

32. Global mapping of binding sites for Nrf2 identifies novel targets in cell survival response through ChIP-Seq profiling and network analysis / D. Malhotra, E. P. Casamar, A Singh [et al.] // Nucleic Acids Res. - 2010. 38 (17). - P. 5718-5734.

33. Tuder R. M. Pathogenesis of chronic obstructive pulmonary disease / R. M. Tuder, I. Petrache // J. Clin. Invest. - 2012. - 122 (8). - P. 2749-2755.

\section{REFERENCES}

1. Khrystych, M., Fediv, O.I., Teleki, Ya.M., \& Olinyk, O.Yu. (2011). Rol tsytokinovoho dysbalansu v rozvytku ta prohresuvanni khronichnoho obstruktyvnoho zakhvoriuvannia lehen iz suputnim khronichnym pankreatytom [The role of cytokine imbalance in the development and progression of chronic obstructive pulmonary disease with concomitant chronic pancreatitis]. Novosti meditsyny i farmatsyi. Gastroenterologiya. Medicine and Pharmacy News. Gastroentherology, 382 [in Ukrainian].

2. Bhandari, R., \& Sharma, R. (2012). Epidemiology of chronic obstructive pulmonary disease: a descriptive study in the mid-western region of Nepal. International Journal of COPD, 7, 253-257.

3. Pertseva, T.A. (2011). Epidemiologiya i diagnostika khronicheskogo obstruktivnogo zabolevaniya legkikh [Epidemiology and diagnosis of chronic obstructive pulmonary disease]. Ukr. pulm. zhurn. - Ukrainian Pulmonology Journal, 2, 20 [in Russian].

4. Alwan, A. (2010). Global status report on noncommunicable diseases. Global Status Report on NonCommunicable Diseases, 176.
5. Bigna, J., Kenne, A.M., Asangbeh, S.L., \& Sibetcheu, A.T. (2018). Prevalence of chronic obstructive pulmonary disease in the global population with HIV: a systematic review and meta-analysis. Lancet Glob Health, 6, 193-202.

6. Stone, H., Nab, G.M., \& Wood, A.M. (2012). Variability of sputum inflammatory mediators in COPD and a1-antitrypsin deficiency Eur. Respir. J., 40, 561-569.

7. Marushchak, M., Krynytska, I., Petrenko, N., \& Klishch, I. (2016). The determination of correlation linkages between level of reactive oxygen species, contents of neutrophiles and blood gas composition in experimental acute lung injury Georgian Med. News, 253, 98-103.

8. Tuder, M.R., \& Petrache, I. (2012). Pathogenesis of chronic obstructive pulmonary disease. J. Clin. Invest., 122 (8), 2749-2755.

9. Kohen, R., \& Nyska, A. (2002). Oxidation of biological systems: oxidative stress phenomena, antioxidants, redox reactions, and methods for their quantification. Toxicol. Pathol., 30 (6), 620-650.

10. Shishko, G.A., Sapotnitskiy, A.V., \& Ustinovich, Yu.A. (2011). Rol oksidativnogo stressa v pato- 
geneze zabolevaniy novorozhdennykh detey [The role of oxidative stress in the pathogenesis of diseases of newborns]. Belorusskaya meditsinskaya akademiya poslediplomnogo obrazovaniya - Belarusian Medical Academy of Postgraduate Education, 6, 22-24 [in Russian].

11. Mishra, O.P., \& Papadopoulos, M.D. (1999). Cellular mechanisms of hypoxic injury in the developing brain. Brain Res. Bull., 48, 233-238.

12. Li, X., Fang, P., \& Mai, J. (2013). Targeting mitochondrial reactive oxygen species as novel therapy for inflammatory diseases and cancers. J. Hematol. Oncol., 6, 1-19.

13. West, A. P., Shadel, G.S., \& Ghosh, S. (2011). Mitochondria in innate immune responses. Nat. Rev. Immunol., 11 (6), 389-402.

14. Dada, L.A., \& Sznajder, J.L. (2011). Mitochondrial $\mathrm{Ca}^{2+}$ and ROS take center stage to orchestrate TNF-a-mediated inflammatory responses. J. Clin. Invest, 121 (5), 1683-1685.

15. Balabolkin, M.I., Kreminskaya, V.M., \& Klebanova, E.M. (2005). Rol okislitelnogo stressa v patogeneze diabeticheskoy neyropatii i vozmozhnost yego korrektsii preparatimi a-lipoyevoy kisloty [The role of oxidative stress in the pathogenesis of diabetic neuropathy and the possibility of its correction by preparations of $\alpha$-lipoic acid]. Problemy endokrinologii - Problems of Endocrinology, 51 (3), 22-33 [in Russian].

16. Klymenko, M.O., Subota, N.P., \& Netiukhailo, L.H. (2006). Nefermentatyvna lanka antyoksydantnoi systemy $\checkmark$ rizni stadii eksperymentalnoi opikovoi khvoroby pry vykorystanni preparatu Kriokhor [Non-enzymatic link of antioxidant system at different stages of experimental burn disease with the use of the drug Cryochorus]. Eksperymentalna i klinichna medytsyna - Experimental and Clinical Medicine, 1, 13-17 [in Ukrainian].

17. Imaizumi, Y., Eguchi, K., \& Kario, K. (2015). Lung disease and hypertension. Pulse, 2 (1-4), 103-112.

18. Romero, P.V., Rodríguez, B., \& Martínez, S. (2006). Analysis of oxidative stress in exhaled breath condensate from patients with severe pulmonary infections. Archivos de Bronconeumologia, 42 (3), 113-119.

19. Zhang, W., Wei, H., \& Frei, B. (2009). Genetic deficiency of NADPH oxidase does not diminish, but rather enhances, LPS-induced acute inflammatory responses in vivo. Free Radical Biology and Medicine, 46 (6), 791-798.

20. Mills, M.C., Marchese, M.E., \& Valencia, H.A. (2011). Vascular cell adhesion molecule-1 expression and signaling during disease: regulation by reactive oxygen species and antioxidants. Antioxidants \& Redox Signaling, 15 (6), 1607-1638.

21. Bhoite, G.M., Pawar, S.M., Bankar, M.P., \& Momin, A.A. (2011). Level of antioxidant vitamins in children suffering from pneumonia, 15(1). Retrieved from: https:// www.alliedacademies.org/articles/level-of-antioxidantvitamins-in-children-suffering-from-pneumonia.pdf

22. Netiukhailo, L.H., \& Kharchenko, S.V. (2014). Aktyvni formy kysniu (ohliad literatury) [Active forms of oxygen (review of literature)]. Young Scientist, 9 (12), 131-135 [in Ukrainian].

23. Vaidya, N.A., \& Bulakh, P.M. (2013). Antioxidant enzymes and antioxidants in children with. IOSR Journal of Dental and Medical Sciences, 8 (6), 01-05.

24. Churchill Livingstone. (2005). Principles and practice of infectious diseases. Young EJ, 2669-2672.

25. Klymenko, M.O., \& Netiukhailo, L.H. (2009). Opikova khvoroba (patohenez i likuvannia): Monohrafiia [Burn disease (pathogenesis and treatment): Monograph]. - Poltava [in Ukrainian].

26. Montuschi, P., Barnes, P.J., \& Roberts, L.J. (2004). Isoprostanes: markers and mediators of oxidative stress. FASEB J, 18, 1791-800.

27. Rezaeetalab, F., Alamdari, D.H., \& Dalili, A. (2017). Prooxidant - Antioxidant balance in COPD patients. Pneumologia, 66 (2), 90-93.

28. Rogers, D.F., Chadwick, D., \& Goode, J.A. (2001). Mucus hypersecretion in chronic obstructive pulmonary disease. Chronic obstructive pulmonary disease: pathogenesis to treatment, 65-83.

29. Nadel, J.A. (2001). Role of epidermal growth factor receptor activation in regulating mucin synthesis. Respir. Res., 2, 85-89.

30. Rezaeetalab, F., Alamdari, D.H., \& Dalili, A. (2014). Oxidative stress in COPD, pathogenesis and therapeutic views. Treat Respir. Med., 1(3), 115-124.

31. Higgins, M., \& Thom, T. (1990). Incidence, prevalence, and mortality: intra- and inter-county differences. Clinical Epidemiology of Chronic Obstructive Pulmonary Disease, 23-43.

32. Malhotra, D., Casamar, E.P., \& Singh, A. (2010). Global mapping of binding sites for Nrf2 identifies novel targets in cell survival response through ChIP-Seq profiling and network. Nucleic Acids Res., 38 (17), 5718-5734.

33. Tuder, R.M., \& Petrache, I. (2012). Pathogenesis of chronic obstructive pulmonary. J. Clin. Invest., 122 (8), 2749-2755.

К. Я. Максив, М. И. Марущак ТЕРНОПОЛЬСКИЙ ГОСУДАРСТВЕННЫЙ МЕДИЦИНСКИЙ УНИВЕРСИТЕТ ИМЕНИ И. Я. ГОРБАЧЕВСКОГО

\section{РОЛЬ ОКСИДАТИВНОГО СТРЕССА В РАЗВИТИИ ХРОНИЧЕСКОГО ОБСТРУКТИВНОГО ЗАБОЛЕВАНИЯ ЛЕГКИХ}

\section{Резюме}

Вступление. Распространенность хронического обструктивного заболевания легких (ХОзЛ) продолжает неуклонно расти. По мнению исследователей, к 2030 г. оно станет третьей по значимости причиной смертности. Патофизиология ХОЗЛ сложная и в настоящее время до конца не изучена. Большинство исследователей у больных ХОЗЛ определяет локальные и системные изменения, включающие 
оксидативный стресс, изменение уровней острофразовых протеинов и воспалительных медиаторов, хотя и нет единого мнения относительно их роли при этом заболевании.

В работе использованы общенаучные методы исследования, которые включают экспертно-аналитический обзор научных источников, анализ и синтез литературных данных.

Исследователи отмечают, что перекисное окисление протеинов является не только пусковым механизмом патологических процессов при стрессе, но и одним из наиболее ранних маркеров оксидативного стресса, а также отображением степени окислительного поражения клеток и резервно-адаптационных возможностей организма при ХОЗЛ. Оксидативный стресс ведет к окислению арахидоновой кислоты и фрормированию новой генерации простаноидных медиаторов, так называемых изопростанов, которые могут проявлять выраженные функциональные эфрфекты, включая бронхоконстрикцию и экссудацию плазмы. Негативным эффректам оксидативного стресса в организме противодействуют энзимное и неэнзимное звенья системы антиоксидантной защиты. Высокую антиоксидантную эфрфективность проявляют медь-цинксодержащая супероксиддисмутаза, гемсодержащая каталаза, селенсодержащая глутатионпероксидаза. По результатам анализа литературных источников, внутриклеточный антиоксидант глутатион является главной защитной системой в эпителии легких. Защитные эфрфекты родственной антиоксидантной системы, расположенной в эпителии, вероятно, регулируют гены. Это может быть одной из причин, почему только в 10 \% лиц, которые курят, развивается ХОзЛ.

Цель исследования - проанализировать современные литературные источники о роли свободнорадикальных процессов в механизмах развития хронического обструктивного заболевания легких.

Вывод. Проведенный анализ литературных данных показал, что оксидативный стресс играет весомую роль в патогенезе хронического обструктивного заболевания легких, однако механизмы его воздействия требуют более детального и глубокого исследования.

КЛЮЧЕВЫЕ СЛОВА: хроническое обструктивное заболевание легких; оксидативный стресс; механизмы.

Kh. Ya. Maksiv, M. I. Marushchak I. HORBACHEVSKY TERNOPIL STATE MEDICAL UNIVERSITY

\section{THE ROLE OF OXIDATIVE STRESS IN THE DEVELOPMENT OF CHRONIC OBSTRUCTIVE PULMONARY DISEASES}

\section{Summary}

Introduction. The prevalence of chronic obstructive pulmonary disease (COPD) continues to grow steadily and according to researchers, by 2030 this disease will be the third most significant cause of death. The pathophysiology of COPD is complicated and largely unexplored. Most researchers in patients with COPD determine local and systemic changes that include oxidative stress, changes in levels of acute phase proteins and inflammatory mediators, although there is no single point of view regarding their role in this disease.

We used general scientific research methods.

Researchers noted that peroxide oxidation of proteins is not only a trigger mechanism for pathological stress, but also one of the earliest markers of oxidative stress and reflects the degree of oxidative cell damage and reserve adaptive capacity of the body in case of COPD. Oxidative stress leads to the oxidation of arachidonic acid and the formation of a new generation of prostanoic mediators, the so-called isoprostants, which can exhibit pronounced functional effects, including bronchoconstriction and plasma exudation. To counteract the negative effects of oxidative stress in the body, there are an enzyme and non-zinc levels of the antioxidant defense system. High antioxidant efficacy is manifested by copper-zinc-containing SOD, gem-containing catalase, selenium-containing glutathione peroxidase. Analysis of literary sources suggests that the internal antioxidant glutathione is a loud protective system in the epithelium of the lungs. The protective effects of a related antioxidant system, established in the epithelium, are surprisingly regulated by the genes. This can be one of the reasons why only $10 \%$ of people who smoke has COPD.

The aim of the study - to analyze modern literary sources about the role of free radical processes in the mechanisms of development of chronic obstructive pulmonary disease.

Conclusion. The analysis of literature data showed that oxidative stress plays an important role in the pathogenesis of chronic obstructive pulmonary disease, but the mechanisms of its influence require a more detailed and in-depth study.

KEY WORDS: chronic obstructive pulmonary disease; oxidative stress; mechanisms.

Отримано 22.01.19

Адреса для листування: М. І. Марущак, Тернопільський державний медичний університет імені І. Я. Горбачевського, майдан Волі, 1, Тернопіль, 46001, Україна, e-mail: marushchak@tdmu.edu.ua. 